\title{
Determining Water Salinity in a Shallow Aquifer and Its Vulnerability to Coastline Erosion
}

\author{
Héctor José Peinado-Guevara ${ }^{1 *}$, Omar Delgado-Rodríguez ${ }^{2}$, \\ Jaime Herrera-Barrientos ${ }^{3}$, María de los Ángeles Ladrón de Guevara ${ }^{4}$, \\ Víctor Manuel Peinado-Guevara ${ }^{1}$, Fernando Herrera-Barrientos ${ }^{3}$, \\ Samuel Campista Leon ${ }^{5}$
}

${ }^{1}$ Escuela de Ciencias Económicas y Administrativas, Universidad Autónoma de Sinaloa, Blvd. Juan de Dios Bátiz s/n, San Joachín, Guasave, Sinaloa, México

${ }^{2}$ División de Geociencias Aplicadas, Instituto Potosino de Investigación Científica y Tecnológica,

Camino a la Presa San José 2055, Lomas 4 Sección, San Luis Potosí, S.L.P., México

${ }^{3}$ Centro de Investigación Científica y de Educación Superior de Ensenada, Baja California (CICESE),

Carretera Ensenada-Tijuana No. 3918, Zona Playitas, C.P. 22860, Ensenada, B.C. Mexico; 01(646)175-05-00

${ }^{4}$ Instituto Politécnico Nacional Unidad CIIDIR-Oaxaca, Hornos No. 1003, Noche Buena,

Santa Cruz Xoxocotlán, Oaxaca, México

${ }^{5}$ Facultad de Biología, Universidad Autónoma de Sinaloa, Ciudad Universitaria

Received: 10 February 2017

Accepted: 3 April 2017

\begin{abstract}
In most coastal areas in Mexico, there is an increase in housing development and facilities for tourism, consequently resulting in a negative impact on the environment. Due to this, an awareness of the critical role of groundwater in sustaining coastal populations, economies, and ecosystems is growing. The coastal zone of Sinaloa State is classified as an area with a high presence of saline groundwater in Mexico. The present work was performed in the Las Glorias Beach, Guasave, Sinaloa, Mexico. The results of the analysis of 19 soil and groundwater samples indicate the predominance of sandy soil and a wide range of water salinity, from slightly saline to brine. An electromagnetic profiling (EMP) survey was performed at the study site showing a low apparent electrical conductivity zone parallel to the coastline as indicative of the possible presence of fresh and/or slightly saline water. Apparent electrical conductivity values were compared with electrical conductivity values measured in groundwater samples collected in wells, resulting in a positive linear correlation $(\mathrm{R}=0.97)$. This linear relation is explained by a $\phi$ - $\xi$ electromagnetic analytic model when $5.36 \leq \sigma_{a} \leq 85.87 \mathrm{mS} / \mathrm{cm}$. The linear relation was used to recalculate the apparent electrical conductivity values from EMP survey into electrical conductivity values of groundwater and, therefore, TDS values. The TDS map indicates the presence of a barrier of fresh/slightly saline groundwater parallel to the coastline that keeps a fragile balance that prevents the advance of saltwater intrusion from the sea of Cortés and from brine zones located in the northern part of the site. The advance of erosion in Las Glorias Beach exposes
\end{abstract}

*e-mail: hpeinado75@hotmail.com 
the vulnerability of the aquifer to the saline intrusion to be advancing in time, which has affected the zone economically and socially.

Keywords: electromagnetic profiling, apparent electrical conductivity, soil texture, saltwater intrusion

\section{Introduction}

The coastal zones have been highly exploited both for settlement and for the growth industry, extraction of resources, tourism, and housing, resulting in a big number of negative environmental impacts as accelerated erosion, deposition, eutrophication, sea life destruction, and global decrease of biodiversity [1]. Population and infrastructure growth in those zones should be highly close to the fact of knowing distribution and quality of water for the population on a short-, medium-, and long-term basis, with the aim of planning management and sustainable use.

The exploitation of groundwater causes reductions in water discharge to streams [2], wetlands [3], and coastal estuaries [4], and lowered water levels in ponds and lakes [5]. Contamination of groundwater resources has resulted in the degradation of some drinking water supplies [6]. The proximity of coastal aquifers to saltwater creates unique issues with respect to groundwater sustainability in coastal regions, mainly those of saltwater intrusion into freshwater aquifers and changes in the amount and quality of fresh groundwater discharged to coastal saltwater ecosystems [7]. The advance of saltwater intrusion in the coastal aquifer depends on factors such as the pumping rate of fresh water compared to aquifer recharge, as well as the thickness and hydraulic properties of the aquifer [8]. The coastal zone of Sinaloa is classified as one of the areas with the highest presence of saline groundwater in Mexico [9].

Due to this, dependence on groundwater is higher day after day because of the enormous population growth in coastal areas, [10] as they demand fresh water free of contaminants [11], knowing seasonal and special evolution of water in coast zones is useful for preventing seawater intrusion and to understand the vulnerability of a coastal environment [12]. As groundwater use has increased in coastal areas, so has the recognition that groundwater supplies are vulnerable to overuse and contamination. It is of utmost importance to know the groundwater characteristics such as pore water salinity; for planning and optimal management of the resource in agreement with the nature of real estate development, necessary infrastructure, and the vulnerability of the ecosystems in such zones.

Geophysical techniques, mainly electromagnetic methods, are fast, reliable and widely used to delineate the textural characteristics of the soil [13-14]. The electromagnetic profiling (EMP) method measures the apparent electrical conductivity $\left(\sigma_{a}\right)$ of the soil. The $\sigma_{a}$ values obtained from the EMP method have been used in different ways to estimate special variability of soil properties [15-18] as salinity [19-21], to characterize soils [13, 22-23], defining profiles with soil physical and chemical properties [24], evaluating soil quality [25], determining hydraulic conductivity [26], calculating soil $\mathrm{pH}$ [27], outlining productive zones in agricultural fields [28], and site-specific crop management [29].

Pearson's correlation and the analysis of multiple regressions have been used to determine relations between soil electrical conductivity and other soil properties [30] such as pore water content and soil texture [31]. Archie [32] found a relationship between sand resistivity saturated by brine $\left(\mathrm{R}_{\mathrm{o}}\right)$ and brine resistivity $\left(\mathrm{R}_{\mathrm{w}}\right)$, called formation factor. When the materials are not pure sands (clay content $>0 \%$ ), the relationship $\mathrm{R}_{\mathrm{o}} / \mathrm{R}_{\mathrm{w}}$ is named apparent formation factor. Several authors [33-35] found a relationship between pore water and formation resistivities. Such a relationship has been obtained through surveys in several geological environments. Thus formation resistivity is directly proportional to pore water resistivity, groundwater resistivity [36-38] and it is function of water content, soil porosity, and pore tortuosity.

Las Glorias Beach has seen problems with coastline erosion, which has caused material and economic losses in the region. Likewise, there are records of hydraulic works that have affected the morphology of the coast. The hydraulic infrastructure works built on the tributaries of the Sinaloa River, such as the Guillermo Blake and Gustavo Díaz Ordaz dams (in 1972 and 1981, respectively) significantly altered the contribution of water volumes to the beach, which limited the entrance of sediment, generating an imbalance in the dynamics of the beach, which, together with the construction of the breakwater in 1992 used to rectify and fix the mouth of the Sinaloa River, justified the proposal in which the mouth of the river was moving toward the west and favored changes in the movements of the swells of the beach [39].

These hydraulic works and natural processes have accelerated the retreat of the beaches, highlighting more than $100 \mathrm{~m}$ of erosion during the period 1992-2002 [40]. Due to the tourist and economic potential that the area represents for the inhabitants, an attempt was made to recover the lost land to the sea by building a breakwater, in 2006, in the western portion of Las Glorias; however, the problem continued to progress [41].

In addition to the loss of land, other factors exacerbate the problem, since coastal aquifers are influenced by the dynamics of the sea. Rocha et al. [42] points out that coastal aquifers are characterized by salinity variations with respect to space and time; therefore, the analysis of the relationship between fresh and salt water in the coastal regions creates a state of equilibrium. The interface is dynamic and depends on variations in recharge and extraction [43].

Due to the coastal erosion observed in Las Glorias, we estimated the variability of the coastline in measurements 
with the use of Google Earth satellite images from 1984, 1990, 1994, 2000, 2003, 2005, 2013, and 2016. In this paper, we study the vulnerability of the aquifer to changes in the geomorphology of the coast. The detriment of aquifer water quality not only affects the ecosystem, but also the consumptive use of society.

The aim of this work is to characterize the shallow aquifer in Las Glorias beach, Guasave, Sinaloa, Mexico based on values of groundwater electrical conductivity $\sigma_{w}$ calculated using the linear relation between $\sigma_{a}$ (EMP survey) and $\sigma_{w}$ values (groundwater samples). With this information, the area of study is characterized and the vulnerability of the aquifer is analyzed before natural and anthropogenic processes that have caused erosion of Las Glorias.

\section{Experimental}

\section{Description of the Study Area}

Las Glorias Beach is the main tourist destination of the Guasave municipality, Sinaloa, Mexico. The coastline has an approximate length of $4.8 \mathrm{~km}$. The latitude and longitude coordinates of the studied site are from $25^{\circ} 16^{\prime} 48^{\prime \prime}$ to $25^{\circ} 18^{\prime} 53^{\prime \prime}$ north, and from $108^{\circ} 29^{\prime} 19^{\prime \prime}$ to $108^{\circ} 32^{\prime} 51^{\prime \prime}$ west (see Fig. 1). The site has aeolian soils from the Cenozoic era, Quaternary period. The climate is very dry and hot. The annual average temperature is $25.3^{\circ}$ [44]. The predominant soil is sand [45] and the annual average rainfall is $300 \mathrm{~mm}$ (1962-85) [46].

Electrical conductivity of soil depends on pore water salinity, soil porosity, and moisture, temperature, and texture (clay, sand, and silt content). So pore water conductivity $\left(\sigma_{w}\right)$ influences $\sigma_{a}$ value, especially in sandy soils. Due to the effect of the saline intrusion from the estuary La Piedra and saltwater runoff from the Sinaloa River, the analysis of the groundwater electrical conductivity in Las Glorias is needed.

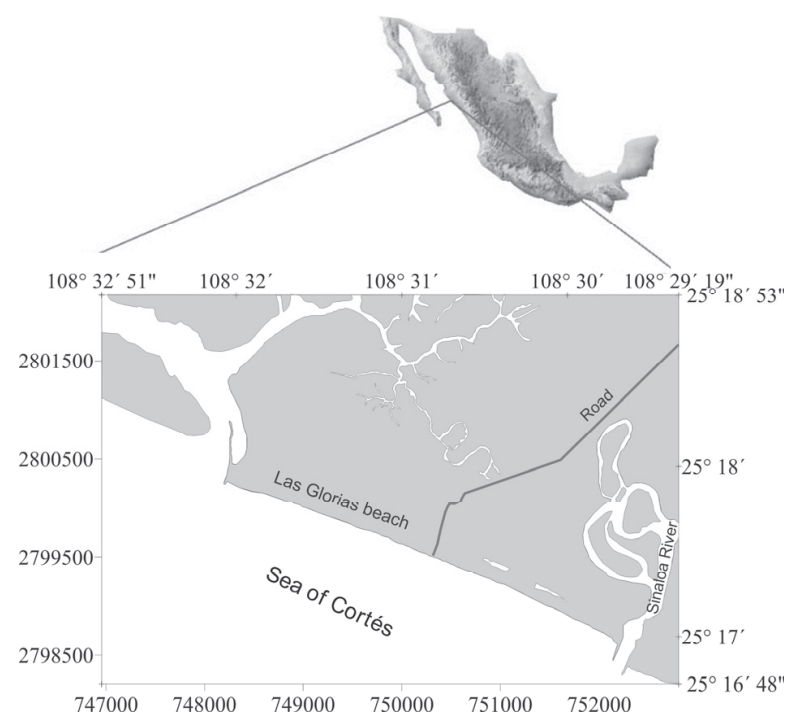

Fig. 1. Location of study area.

\section{Electromagnetic Profiling (EMP)}

The application of the EMP method involves measuring the response of the subsurface to an electromagnetic field. An electromagnetic field is generated by a transmitter antenna, inducing eddy currents within the ground. These induced currents generate a secondary magnetic field. The secondary magnetic field is a function of the inter coil spacing, the operating frequency, and ground conductivity. Both primary and secondary magnetic fields are measured in a receiver antenna. Ground conductivity due to geological characteristics, conductive minerals, clay content, soil moisture and pore water salinity can be calculated from the ratio of the secondary and primary magnetic fields [47]. EMP can quickly determine the horizontal changes in soil conductivity (e.g., different soil texture or moisture) at a specific study depth using the following equation:

$$
\sigma_{a}=\frac{4}{\omega \mu_{0} r^{2}}\left(\frac{H_{s}}{H_{p}}\right)
$$

...where $\sigma_{a}$ is the apparent electrical conductivity of soil (Siemen/m) and:

$\mathrm{H}_{\mathrm{s}}=$ secondary magnetic field measured in the receiver antenna $(\mathrm{mV})$

$\mathrm{H}_{\mathrm{p}}=$ primary magnetic field measured in the receiver antenna $(\mathrm{mV})$

$\omega=2 \pi \mathrm{f}$, where $\mathrm{f}$ is the frequency of EM signal $(\mathrm{Hz})$

$\mu_{0}=$ magnetic permeability of vacuum $(\mathrm{h} / \mathrm{m})$

$\mathrm{r}=$ distance between the transmitter and receiver antennas (m)

In 8,617 EMP measurements points, $\sigma_{a}$ values were obtained using a CMD-1 sensor [48] in vertical polarization, ensuring the detection of conductive bodies (saturated soil) in the depth range 0.5-1.5 m. EMP measurements were performed approximately every five steps, following access paths (roads, trails) to each part of the site. Each measurement was geo-positioned (Fig. 2).

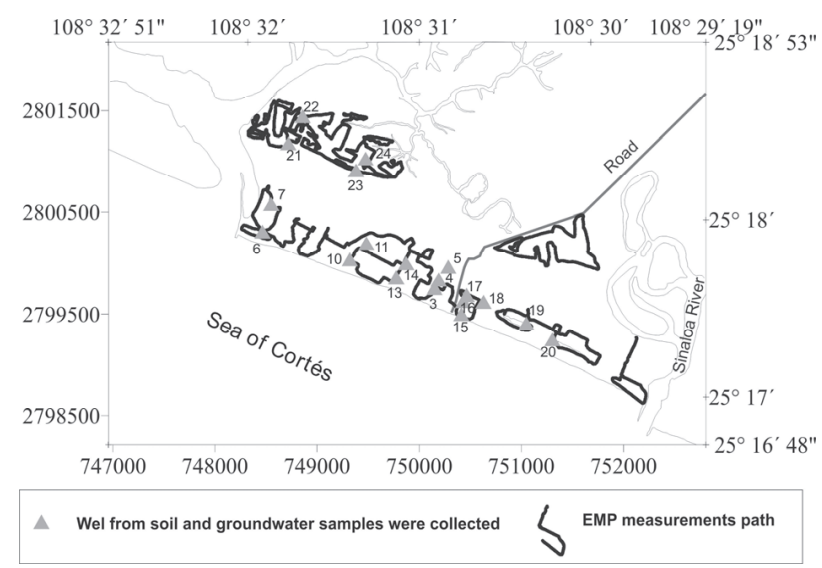

Fig. 2. Locations of wells and EMP measurement points in the study area. 


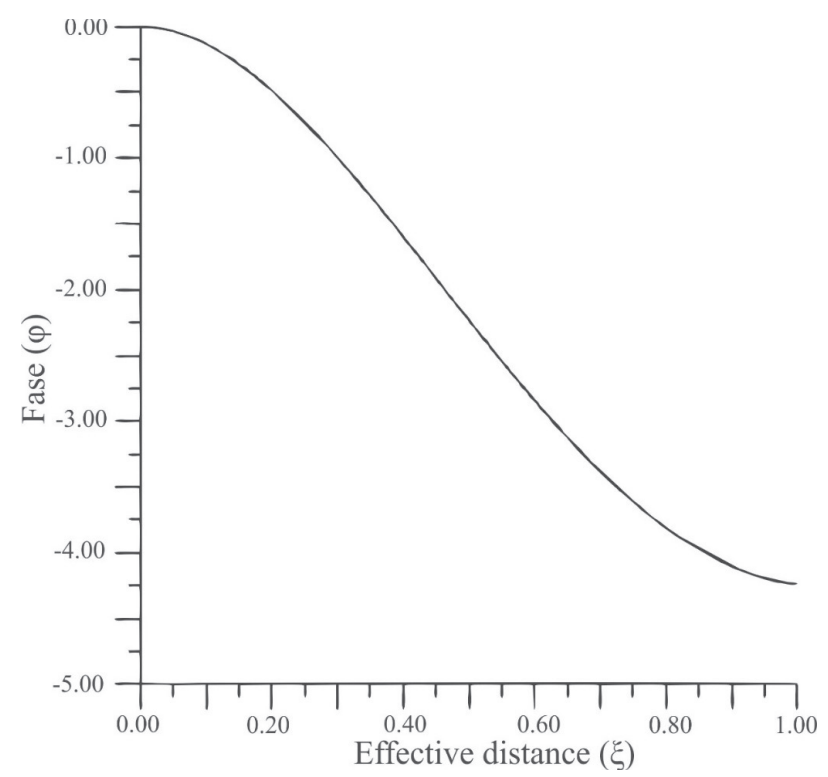

Fig. 3. Relationships in the close zone between phase $(\varphi)$ and effective distance.

\section{Phase of the Vertical Magnetic Dipole}

If a variable current flows through a coil (transmitting coil), as stated before, a magnetic field will be produced traveling through the surrounding media. If the media is a homogeneous and isotropic conveying land, such a field will induce electrical currents through the same, producing a secondary or induced magnetic field, its intensity is highly influenced by electrical conductivity (Fig. 3) from the conducting media (subsoil). GF instruments [49] state that for a distance several times the horizontal coil diameter, the magnetic field of such a coil behaves as that from an oscillating dipole when being over the homogeneous and isotropic conveying land, its vertical component at an $r$ distance from the transmitting coil is:

$B_{z}=-\frac{i \mu_{o} m}{2 \pi \xi^{2} r^{3}}\left[9-\left(9-9 i^{3 / 2} \xi-4 i \xi^{2}-i^{1 / 2} \xi^{3}\right) e^{i \sqrt{i \xi}}\right]$

w.where:
$i=\sqrt{-1}$

$\mathrm{m}$ is the moment of the coil

$$
\begin{array}{r}
\mu_{\mathrm{o}}=4 \pi \times 10^{-7} \text { henrio } / \mathrm{m} \\
\xi=\left|\gamma_{1} r\right|=r \sqrt{\omega \mu_{o} \sigma}
\end{array}
$$

The vertical component of the magnetic field is a complex number, therefore (2) can be expressed as follows:

$$
B_{z}=a+b i
$$

$\ldots$ where a an $b$ are real quantities, then the phase $(\varphi)$ of $B_{z}$ is:

$$
\phi=\tan ^{-1}\left(\frac{b}{a}\right)
$$

Developing (2), values a and $\mathrm{b}$ are obtained resulting in:

$$
\begin{gathered}
a=\beta\left(\left(9+9 \alpha \xi-\alpha \xi^{3}\right) e^{-\alpha \xi} \operatorname{sen}(\alpha \xi)-(9 \alpha \xi+\right. \\
\left.\left.+4 \xi^{2}+\alpha \xi^{3}\right) e^{-\alpha \xi} \operatorname{sen}(\alpha \xi)\right)
\end{gathered}
$$

$$
\begin{aligned}
b=\beta(9- & \left(9+9 \alpha \xi-\alpha \xi^{3}\right) e^{\alpha \xi} \cos (\alpha \xi)-(9 \alpha \xi+ \\
& \left.\left.+4 \xi^{2}+\alpha \xi^{3}\right) e^{-\alpha \xi} \operatorname{sen}(\alpha \xi)\right)
\end{aligned}
$$

... where:

$$
\alpha=\frac{\sqrt{2}}{2} \text { у } \beta=\frac{-\mu_{o} m}{2 \pi \xi^{2} r^{3}}
$$

Taking into account that the CMD-1 sound works at a $10,000 \mathrm{~Hz}$ frequency, then the $\mathrm{r}$ measuring distance of $0.98 \mathrm{~m}$ and the value of magnetic permeability of vacuum stated by (3) is close to the land, then the effective distance (६) takes the shape:

$$
\xi=0.273 \sqrt{\sigma}
$$

As observed from equations (5), (6), and (7), the phase is a function of $\xi$ and this of $\sigma(\mathrm{S} / \mathrm{m})$, then:

$$
\phi=f(\sigma)
$$

For $\xi \ll 1$ values, this means, in the close zone, the relationship between $\xi$ and $\varphi$ can be considered as linear (see Fig. 3). The relationship can be:

$$
\frac{\phi_{1}-\varphi_{2}}{\xi_{2}-\xi_{1}}=\frac{\phi_{2}-\phi_{3}}{\xi_{3}-\xi_{2}}
$$

Considering (8) in (10):

$$
\frac{\phi_{1}-\phi_{2}}{\phi_{2}-\phi_{3}}=\frac{\sqrt{\sigma_{2}}-\sqrt{\sigma_{1}}}{\sqrt{\sigma_{3}-\sqrt{\sigma_{2}}}}
$$

...(10) and (11) are valid when the relationship between $\phi$ and $\xi$ is linear, that is when $0.2 \leq \xi \leq 0.8$ (Fig. 3). That is, from agreement to (8) $5.36 \leq \sigma_{a} \leq 85.87 \mathrm{mS} / \mathrm{cm}$.

For example, in the linear zone, when $\sigma_{a}$ is 20, 40, and $60 \mathrm{mS} / \mathrm{cm}$, respectively, so $\xi$ will be $0.380,0.546$, and 
0.668 , respectively. The corresponding $\phi$ values are -1.47 , -2.48 , and -3.22 . These values satisfy the relationship between 10 and 11 .

\section{Groundwater and Soil Sampling}

Nineteen drillings up to $2.5 \mathrm{~m}$ deep were performed with the aim of finding the relationship between $\sigma_{w}$ and $\sigma_{a}$ for the local shallow aquifer. In each well soil and groundwater samples were collected. The wells were geolocated using a portable GPS (Fig. 2). $\mathrm{pH}, \sigma_{w}$, and TDS values were obtained in situ for the 19 groundwater samples using a HI98130 portable. Texture was determined in each soil sample according to NOM-021-RECNAT-2000 [50] using the Bouyoucos method [51].

Groundwater salinity is classified according to TDS content, taking into account the following ranks: $<1,000 \mathrm{mg} / 1$ is fresh water; from 1,000 to $3,000 \mathrm{mg} / 1$ slightly saline, from 3,000 to $10,000 \mathrm{mg} / 1$ moderately saline, from 10,000 to 35,000 highly saline, and over $35,000 \mathrm{mg} / \mathrm{l}$ brine [52].

\section{Google Earth Image Processing}

Google Earth satellite images of 1984, 1990, 1994, 2000, 2003, 2005, 2013, and 2016 were digitized to determine the variability of the coastline over time. Using three profiles to obtain the relationship between erosion and time, this is predicted on the trend of the coastline in the future. The images of 1990, 1994, 2000, 2003, 2013, and 2016 show the effect of the rectification of the Sinaloa River in 1992 and its effects - as well as the spike built in 2006 on the morphology of the study area. Fig. 4 shows changes in the morphology of the coastline in the study area from 1990 to 2016: Fig. 4a) shows where the Sinaloa flowed and Fig. 4b) shows As change from the construction of the breakwater in 1992. When changing the mouth of the Sinaloa, the modified section was sprinkling and practically disappeared by 2016. Also, in Figs 4(e-f) you can see the effects caused by the spigot in the western portion and the erosion-related processes.

\section{Results and Discussion}

Table 1 shows the soil texture (sand, silt, clay), groundwater table (GWT) depth, $\sigma_{w}, \mathrm{pH}$, TDS, and $\sigma_{a}$ values for 19 soils. The $\sigma_{a}$ values were obtained from EMP measurement points located near wells. A pH interval of $6.38-8.09$, with an average of 7.25 , is observed, indicating a slight tendency to a basic composition. The $\sigma_{w}$ values vary from 0.89 to $88.6 \mathrm{mS} / \mathrm{cm}$, with an average value of

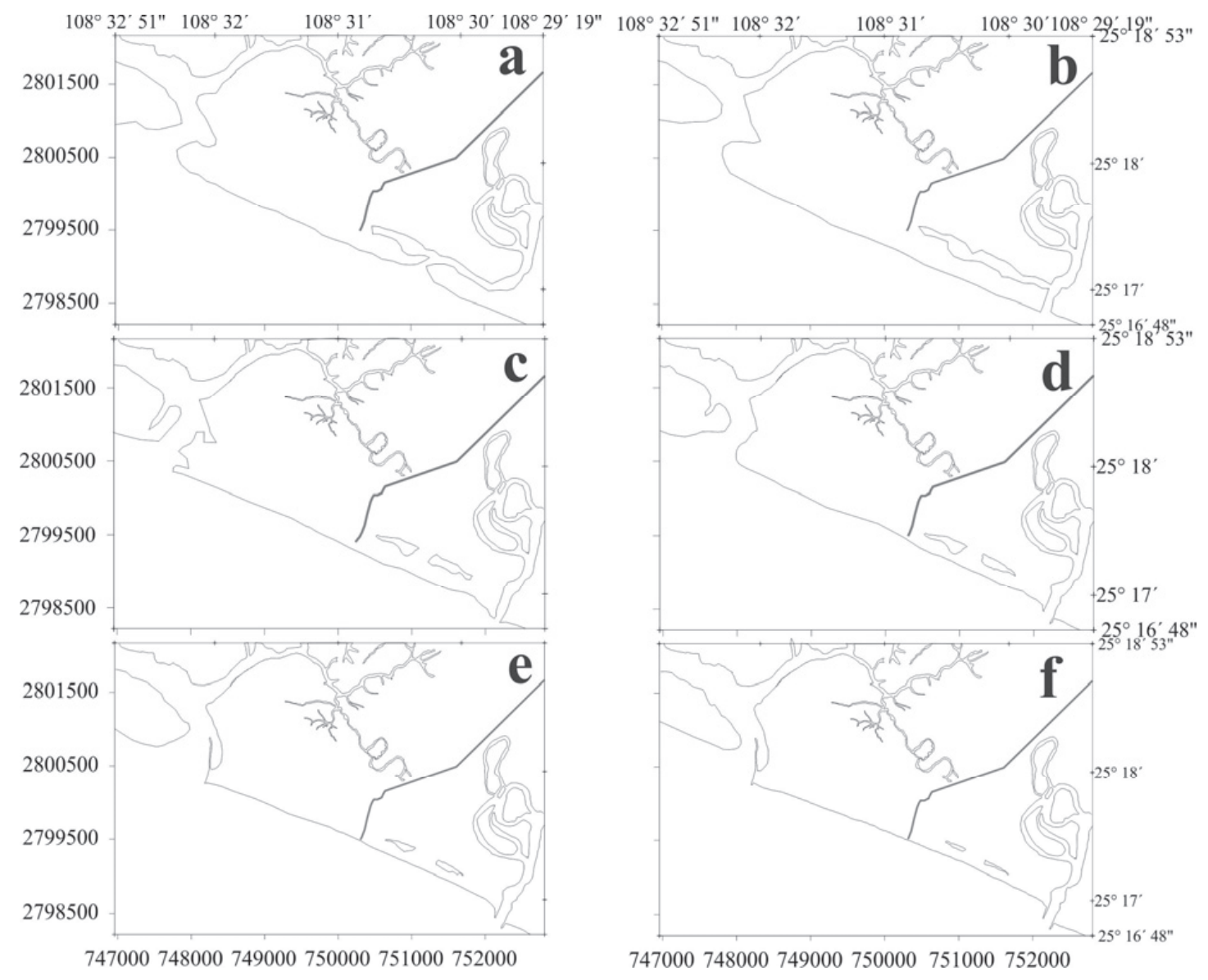

Fig. 4. Changing the morphology of the study area from satellite imagery of Google Earth: a) 1990, b) 1994, c) 2000, d) 2003, f) 2013 , and g) 2016 . 
Table 1. Parameters measured in wells as a result of drillings and application of the EMP method.

\begin{tabular}{|c|c|c|c|c|c|c|c|c|c|c|}
\hline \multirow[b]{2}{*}{ Well } & \multicolumn{2}{|c|}{ UTM coordinates } & \multicolumn{4}{|c|}{ Groundwater samples } & \multirow{2}{*}{$\begin{array}{c}\mathrm{EMP}^{\mathrm{b}} \\
\begin{array}{c}\sigma_{a} \\
(\mathrm{mS} / \mathrm{cm})\end{array}\end{array}$} & \multicolumn{3}{|c|}{ Soil texture } \\
\hline & $X$ & Y & $\begin{array}{c}\text { GWT }^{\mathrm{a}} \text { depth } \\
\text { (m) }\end{array}$ & $\begin{array}{c}\sigma_{w} \\
(\mathrm{mS} / \mathrm{cm})\end{array}$ & $\mathrm{pH}$ & $\begin{array}{l}\text { TDS } \\
\text { (ppm) }\end{array}$ & & $\begin{array}{c}\% \\
\text { Sand }\end{array}$ & $\begin{array}{c}\% \\
\text { Silt }\end{array}$ & $\begin{array}{c}\% \\
\text { Clay }\end{array}$ \\
\hline P3 & 750,137 & $2,799,749$ & 1.30 & 2.74 & 7.20 & 1,754 & 0.56 & 88.92 & 9.60 & 1.48 \\
\hline P4 & 750,178 & $2,799,829$ & 1.40 & 2.70 & 7.31 & 1,728 & 0.35 & 88.92 & 9.80 & 1.28 \\
\hline P5 & 750,273 & $2,799,955$ & 2.15 & 5.15 & 7.15 & 3,296 & 0.56 & 88.92 & 9.80 & 1.28 \\
\hline P6 & 748,455 & $2,800,303$ & 1.60 & 10.89 & 7.44 & 6,970 & 1.09 & 94.92 & 3.80 & 1.28 \\
\hline P7 & 748,540 & $2,800,574$ & 1.07 & 7.80 & 7.64 & 4,992 & 2.07 & 92.92 & 5.80 & 1.28 \\
\hline P10 & 749,310 & $2,800,029$ & 1.30 & 1.96 & 8.19 & 1,254 & 0.31 & 92.92 & 5.80 & 1.28 \\
\hline P11 & 749,470 & $2,800,189$ & 1.30 & 8.36 & 7.62 & 5,350 & 0.77 & 92.92 & 5.80 & 1.28 \\
\hline P13 & 749,763 & $2,799,851$ & 1.60 & 4.20 & 7.12 & 2,688 & 1.13 & 92.92 & 5.80 & 1.28 \\
\hline P14 & 749,860 & $2,799,990$ & 1.20 & 2.30 & 7.39 & 1,472 & 0.68 & 92.92 & 5.80 & 1.28 \\
\hline P15 & 750,401 & $2,799,494$ & 0.60 & 29.30 & 6.56 & 18,752 & 6.55 & 90.92 & 7.80 & 1.28 \\
\hline P16 & 750,418 & $2,799,621$ & 0.60 & 4.26 & 7.60 & 2,726 & 0.66 & 90.92 & 7.28 & 1.80 \\
\hline P17 & 750,452 & $2,799,681$ & 0.30 & 2.07 & 7.77 & 1,325 & 0.43 & 94.92 & 1.28 & 3.80 \\
\hline P18 & 750,615 & $2,799,615$ & 1.20 & 2.27 & 7.66 & 1,453 & 0.77 & 94.92 & 3.28 & 1.80 \\
\hline P19 & 751,034 & $2,799,404$ & 0.30 & 32.08 & 7.16 & 20,531 & 6.38 & 88.92 & 7.28 & 3.80 \\
\hline P20 & 751,291 & $2,799,245$ & 0.40 & 31.26 & 7.10 & 20,006 & 7.17 & 94.92 & 3.28 & 1.80 \\
\hline $\mathrm{P} 21$ & 748,707 & $2,801,171$ & 0.90 & 53.64 & 6.50 & 34,330 & 11.05 & 14.92 & 69.28 & 15.80 \\
\hline P22 & 748,849 & $2,801,435$ & 1.20 & 47.01 & 6.45 & 30,086 & 11.24 & 18.92 & 59.28 & 21.80 \\
\hline P23 & 749,369 & $2,800,908$ & 0.60 & 88.60 & 6.38 & 56,704 & 13.80 & 18.92 & 59.28 & 21.80 \\
\hline P24 & 749,424 & $2,801,024$ & 0.65 & 65.20 & 6.59 & 41,728 & 10.57 & 26.92 & 67.28 & 5.80 \\
\hline
\end{tabular}

${ }^{\text {a }}$ GWT $=$ Groundwater table

${ }^{\mathrm{b}} \mathrm{EMP}=$ Electromagnetic profiling

$18.79 \mathrm{mS} / \mathrm{cm}$, according to a high variation of TDS values. These values comprise the portion of theoretical linearity $\left(5.36 \leq \sigma_{a} \leq 85.87 \mathrm{mS} / \mathrm{cm}\right)$ of the electrical conductivity established in Eq. 8, so that the relationship between the apparent electrical conductivity and that of the water of the formation can be explained by the phase- $\xi$ relationship. ECa measurements should be used to characterize subsurface variability of experimental sites [53].

Sandy soils with clay content lower than $2 \%$ are predominant. Only three soil samples have high clay content (from 16 to $22 \%$ ), but salinity groundwater greater than $30 \mathrm{~g} / 1$ ensures a linear relation between soil and pore water resistivity (or its inverse, conductivity) values. Salinity is significantly influenced by the depth of sampling and soil texture [19].

We performed a linear regression using STATISTICS software, taking into account eight parameters: NE, $\sigma_{w}, \mathrm{pH}, \mathrm{TDS}, \sigma_{a}$, sand, silt, and clay. Table 2 shows the obtained correlation results.

Table 2 shows that $\sigma_{w}$ is related to $\sigma_{a}(\mathrm{R}=0.97)$, and there are also relationships among $\sigma_{a}-\mathrm{pH}, \sigma_{a}-\%$ sand, $\sigma_{a}-\%$ limo, and $\sigma_{a}-\%$ clay with $\mathrm{R}=-0.77,-0.83,0.80$, and 0.80 , respectively. It is remarkable that the greatest linear correlation is between $\sigma_{w}$ and $\sigma_{a}$. The best linear adjustment (Fig. 5) is in the high values of electrical conductivity, when it is greater than $6 \mathrm{mS} / \mathrm{cm}$, which is explained by the relationship $\varphi-\xi$. Various calibration methods have been proposed to determine profiles of apparent bulk soil electrical conductivity and soil electrical conductivity of a saturated soil paste extract using an electromagnetic induction instrument $[20,54]$. Therefore, it is feasible to apply it in the study area.

The correlation graph for $\sigma_{a}$ and $\sigma_{w}$ is presented in Fig. 5 , where we can observe a positive and almost perfect linear correlation $(\mathrm{R}=0.97)$. The values form two groups. Group A consists of those samples of sandy soil, i.e., low clay content, so the $\sigma_{a}$ value is closely linked to $\sigma_{w}$ (electrical conductivity). Group B consists of those soil samples saturated with highly salinated water, decreasing the effect of the electrical double layer of the clay and, therefore, the surface conductivity, prevailing again over electrical conductivity.

The equation of the linear correlation is:

$$
\sigma_{w}=5.37 \sigma_{a}-0.37
$$


Table 2. Correlation matrix of eight variables calculated using data obtained from analysis of groundwater and soil samples collected in wells.

\begin{tabular}{|c|c|c|c|c|c|c|c|c|}
\hline & $\mathrm{GWT}^{\mathrm{a}}$ & $\sigma_{\mathrm{w}}$ & $\mathrm{pH}$ & $\mathrm{TDS}$ & $\sigma_{\mathrm{a}}$ & Sand & Silt & Clay \\
\hline $\mathrm{GWT}$ & 1.00 & -0.44 & 0.21 & -0.44 & -0.44 & 0.20 & -0.18 & -0.22 \\
\hline$\sigma_{\mathrm{w}}$ & -0.44 & 1.00 & $\mathbf{- 0 . 7 7}$ & 1.00 & $\mathbf{0 . 9 3}$ & $\mathbf{- 0 . 8 3}$ & $\mathbf{0 . 8 0}$ & $\mathbf{0 . 8 0}$ \\
\hline $\mathrm{pH}$ & 0.21 & $-\mathbf{0 . 7 7}$ & 1.00 & $\mathbf{- 0 . 7 7}$ & $\mathbf{- 0 . 7 4}$ & $\mathbf{0 . 5 9}$ & $\mathbf{- 0 . 5 6}$ & $\mathbf{- 0 . 6 1}$ \\
\hline $\mathrm{TDS}$ & -0.44 & 1.00 & $\mathbf{- 0 . 7 7}$ & 1.00 & $\mathbf{0 . 9 3}$ & $\mathbf{- 0 . 8 3}$ & $\mathbf{0 . 8 0}$ & $\mathbf{0 . 8 0}$ \\
\hline$\sigma_{\mathrm{a}}$ & -0.44 & $\mathbf{0 . 9 3}$ & $\mathbf{- 0 . 7 4}$ & 0.93 & 1.00 & $\mathbf{- 0 . 8 4}$ & $\mathbf{0 . 8 1}$ & $\mathbf{0 . 8 2}$ \\
\hline Sand & 0.20 & -0.83 & 0.59 & -0.83 & -0.84 & 1.00 & $\mathbf{- 0 . 9 9}$ & $\mathbf{- 0 . 8 9}$ \\
\hline Silt & -0.18 & $\mathbf{0 . 8 0}$ & -0.56 & $\mathbf{0 . 8 0}$ & $\mathbf{0 . 8 1}$ & $\mathbf{- 0 . 9 9}$ & 1.00 & $\mathbf{0 . 8 2}$ \\
\hline Clay & -0.22 & $\mathbf{0 . 8 0}$ & $\mathbf{- 0 . 6 1}$ & $\mathbf{0 . 8 0}$ & $\mathbf{0 . 8 2}$ & $\mathbf{- 0 . 8 9}$ & $\mathbf{0 . 8 2}$ & 1.00 \\
\hline
\end{tabular}

${ }^{\mathrm{a}} \mathrm{GWT}=$ Groundwater table

Although Himi et al. [54] found a linear relationship $\left(\sigma_{w}=12.424 \sigma_{a}+29.164\right)$ similar to that found in the present study, they worked with depths of less than $10 \mathrm{~m}$ with the configuration of dipoles $10 \mathrm{HD}$ (horizontal dipole). Equation 12 is used to recalculate the $\sigma_{a}$ values obtained from EMP survey into $\sigma_{w}$ values, and then determine TDS groundwater values for the shallow aquifer.

Fig. 6 presents the behavior of soil $\sigma$. What is remarkable is the presence of a low conductivity anomaly parallel to the coastline. This anomaly may be associated with low levels of pore water salinity. It is worth noting that in some wells drilled in this zone (Fig. 2 and Table 1), groundwater samples showed levels of slight and moderate salinity.

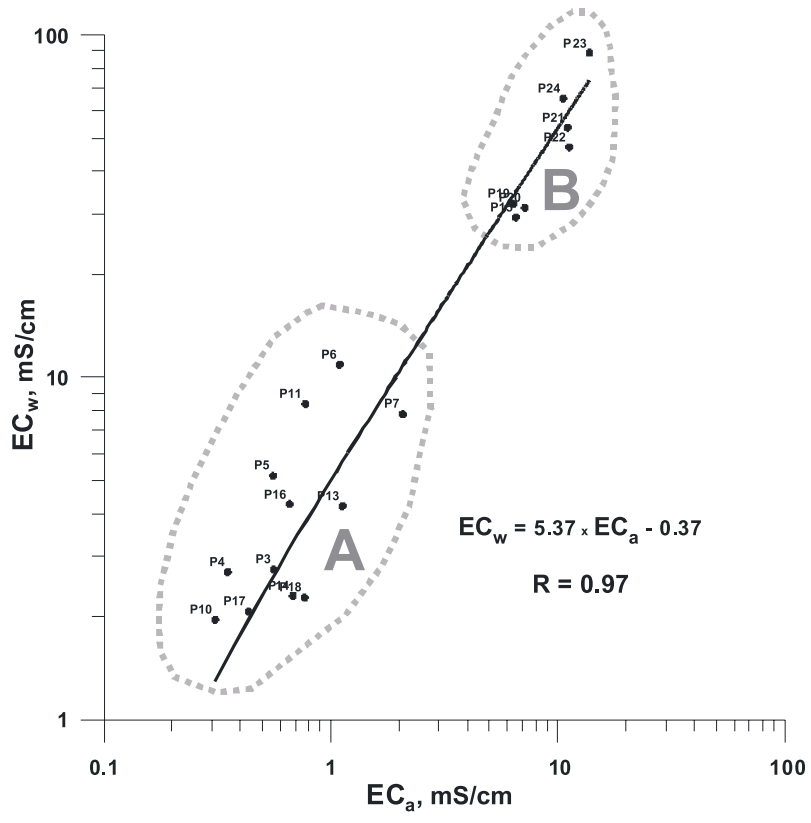

Fig. 5. Linear correlation between electrical conductivity of groundwater $\left(\mathrm{EC}_{\mathrm{w}}\right)$ and apparent electrical conductivity of soil $\left(\mathrm{EC}_{\mathrm{a}}\right)$.
Fig. 7 shows a map of values $\sigma_{w}$, highlighting - similar to the map of Fig. 6 - the presence of the anomaly of low electrical conductivity of the groundwater.

Taking into account the linear function (logarithmic scale) of water resistivity versus salinity, for a reference temperature equal to $20^{\circ} \mathrm{C}$ it is possible to estimate water

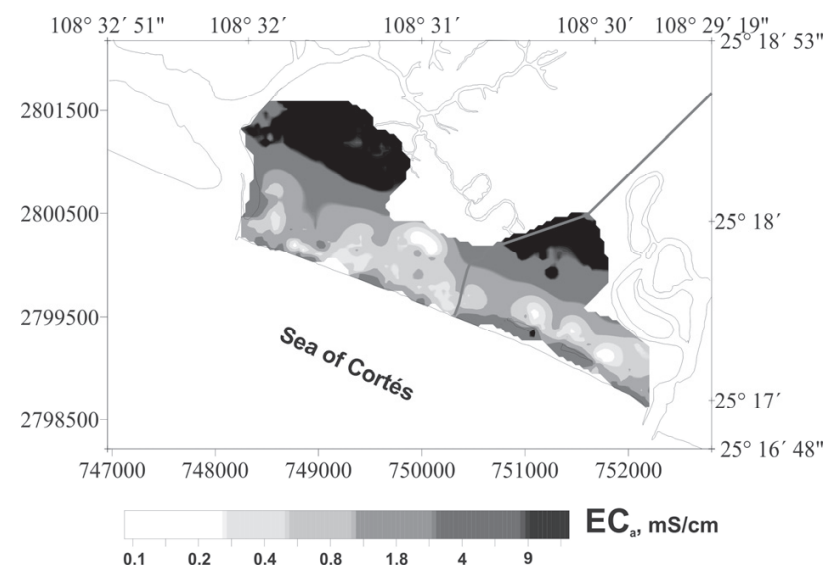

Fig. 6. Map of apparent electrical conductivity of soil.

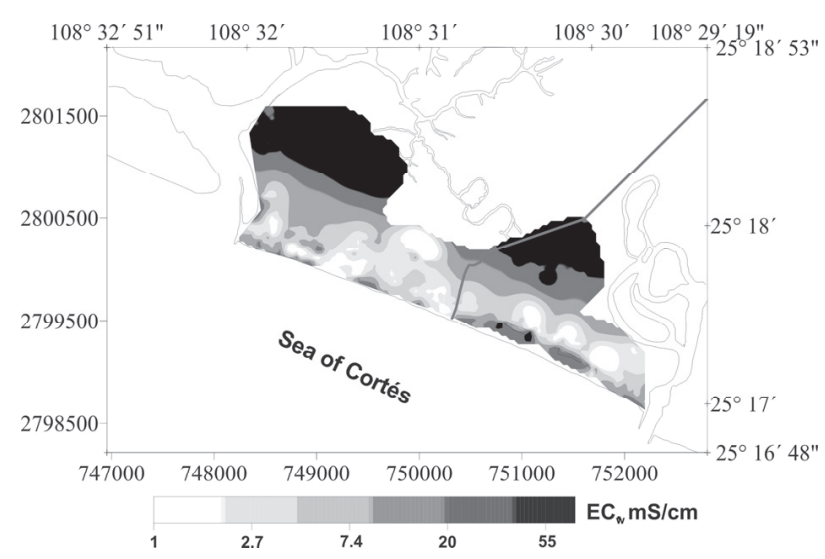

Fig. 7. Map of electrical conductivity of groundwater for the shallow aquifer. 


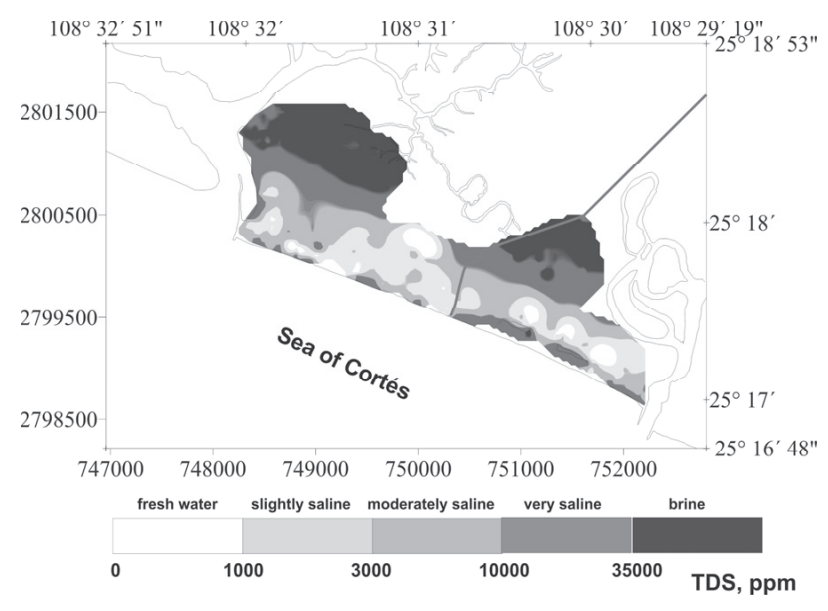

Fig. 8. Map of groundwater salinity of the shallow aquifer.

salinity from water electrical resistivity (or its inverse, conductivity) using the relationship:

$$
\mathrm{TDS}=640 * \sigma_{w}
$$

... where TDS is the salt content ( $\mathrm{NaCl}$ equivalent) in ppm and $\sigma_{w}$ is electrical conductivity of groundwater in $\mathrm{mS} / \mathrm{cm}$.

TDS values for the groundwater were determined using equation (13), which has been applied in other geological environments by various authors [55-57]. As expected, a low TDS anomaly is observed in the map of Fig. 8, showing the existence of fresh and slightly saline pore water. This anomaly is presented as a barrier that keeps a fragile balance between the shallow aquifer and the saline intrusions from both the Sea of Cortés and brines from Sinaloa River and La Piedra Estuary in the northern territory of the study area.

Based on the historical images of Google Earth from 1980, 1990, 1994, 2000, 2003, 2005, 2013, and 2016, three profiles were used to identify erosion behavior in Las Glorias Beach, applying linear regressions, considering coastline by year analyzed, and being adjusted higher than 0.93 in the model. The results show that, as the distance is greater relative to the west of the Sinaloa River, the slope decreases (see Fig. 9). The three profiles show that erosion continues to advance and that, in order to extend its tendency, it will put more pressure on the coastal aquifer by modifying the zone, which agrees with what has been expressed by different authors who have studied the effect of the spike [40-41] and breakwater [39] on the morphology of Las Glorias.

From 1980 to 2016 the erosion has modified the coastline $300 \mathrm{~m}$ - approximately into the sea in Las Glorias. Reyes et al. [58] mention that the changes that occurred on the coastline are due to several factors, including sediment flowing from river to sea, its level variation, influence of activities hydrodynamics of the near-shore, storms, and the nature of coastal geographic features.

Regardless of the cause of the erosion of the coastline at Las Glorias beach, we observed that the tendency to continue with the erosion process and the repercussions are also on the aquifer as the balance between groundwater and sea.
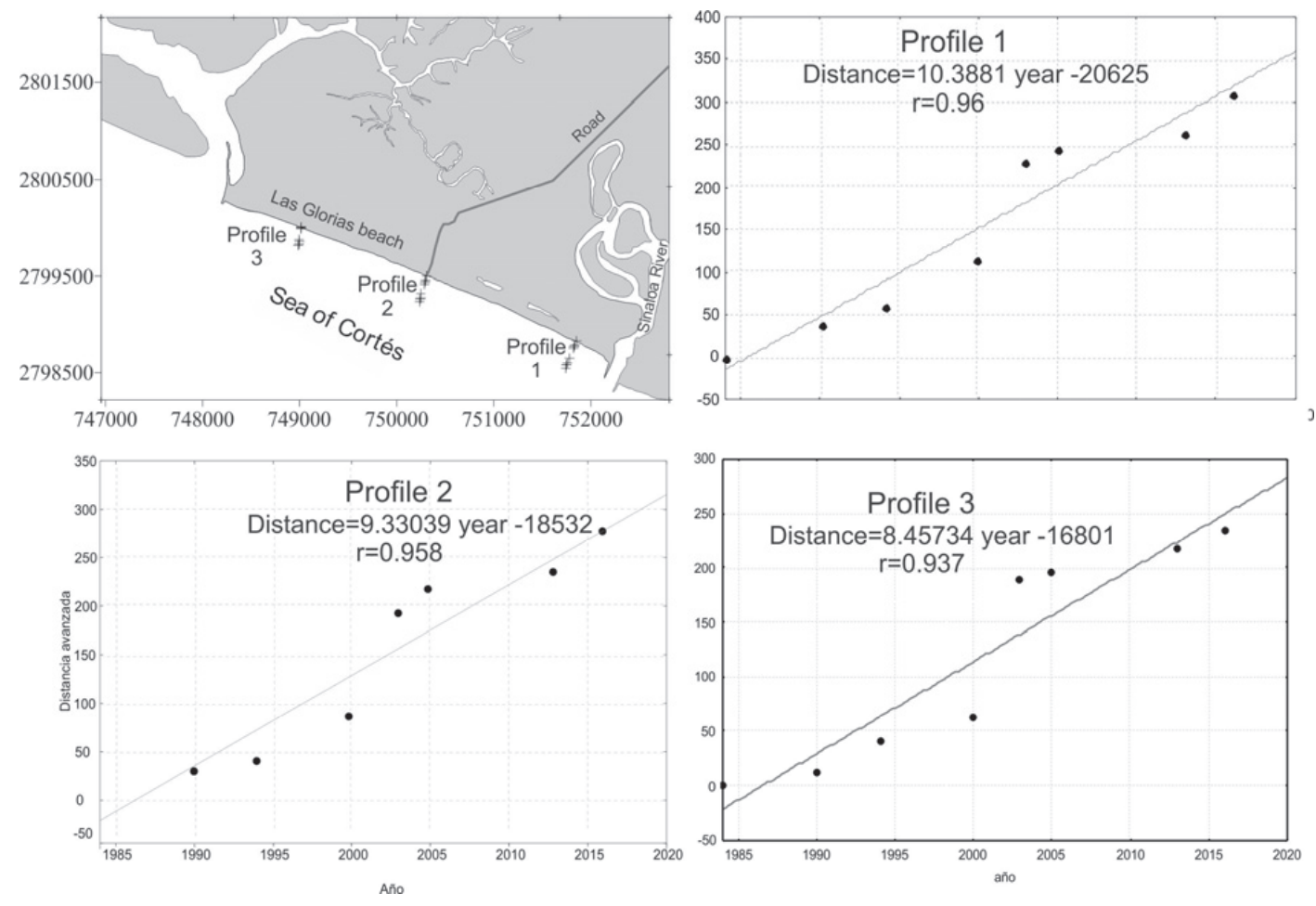

Fig. 9. Profiles on the Sinaloa River from satellite imagery provided by Google Earth. 


\section{Conclusions}

The present work was performed at Las Glorias Beach, Guasave, Sinaloa, Mexico. The shallow aquifer Playas Las Glorias was characterized based on EMP measurements, as well as electrical conductivity measurements in groundwater samples and textural analysis of saturated soil samples. The results of the analysis of 19 soil and groundwater samples indicate the predominance of sandy soil and a wide range of water salinity, from slightly saline to brine. The almost perfect linear correlation was determined between electrical conductivity of groundwater $\left(\sigma_{w}\right)$ and apparent electrical conductivity $\left(\sigma_{a}\right)$ of soil near each well, allowed to recalculate $\sigma_{w}$ values into TDS values for shallow aquifer. The best linear adjustment in the high values of electrical conductivity can be explained by the $\varphi-\xi$ analytical model.

Areas A and B in Fig. 5 showed a low conductivity anomaly related to the presence of low-salinity groundwater. This anomalous zone is presented on a TDS map as a barrier of fresh and slightly saline groundwater, which allows for a balance between the shallow aquifer and salt intrusions from the Sea of Cortés and brine zones located in the northern part of the study area. The advance of the erosion in Las Glorias beach exposes the vulnerability of the aquifer to the saline intrusion to be advancing in time, which has affected the zone economically and socially.

\section{Acknowledgements}

Our gratitude to the General Direction of Research and Post graduate of the Autonomous University of Sinaloa for supporting the project and generating suitable conditions for fulfilling the present work.

\section{References}

1. MASRIA A., NEGM A., ISKANDER M., SAAVEDRA O. Coastal zone issues: a case study (Egypt). Procedia Engineering, 70, 1102, 2014.

2. MALLARD J., MCGLYNN B., COVINO T. Lateral inflows, stream-groundwater exchange, and network geometry influence stream water composition. Water Resources Research, 50 (6), 4603, 2014.

3. CUSTODIO, E. (2001). Groundwater and wetlands. The Spanish strategic plan for the conservation and wise use of wetlands, within the framework of the aquatic ecosystems on which they depend, Fundación Marcelino Botín, 2001 [In Spanish].

4. RUSSONIELLO C.J., KONIKOW L.F., KROEGER K.D., FERNANDEZ C., ANDRES A.S., MICHAEL, H.A. Hydrogeologic controls on groundwater discharge and nitrogen loads in a coastal watershed. Journal of Hydrology, 538, 783, 2016.

5. KIDMOSE J., NILSSON B., ENGESGAARD P., FRANDSEN M., KARAN S., LANDKILDEHUS F., SØNDERGAARD M., JEPPESEN E. Focused groundwater discharge of phosphorus to a eutrophic seepage lake
(Lake Væng, Denmark): implications for lake ecological state and restoration. Hydrogeology Journal, 21 (8), 1787, 2013.

6. AGUDO P. A. Global water crisis: values and rights at stake. Cristianisme i Justicia. Barcelona, 22, 2010 [In Spanish].

7. WERNER A.D., BAKKER M., POST V.E., VANDENBOHEDE A., LU C., ATAIE-ASHTIANI B., SIMMONS C.T., BARRY D.A. Seawater intrusion processes, investigation and management: recent advances and future challenges. Advances in Water Resources, 51, 3, 2013.

8. BARLOW P. M., REICHARD E. G. Saltwater intrusion in coastal regions of North America. Hydrogeology Journal, 18 (1), 247, 2010.

9. MARIN L.E. Perspectives on Mexican ground water resources. Ground Water 40, 570, 2002.

10. LATHAMANI R., JANARDHANAM. R., MAHALINGAM B., SURESHA S. Evaluation of aquifer vulnerability using drastic model and GIS: a case study of Mysore city, Karnataka, India. Aquatic Procedia, 4, 1031, 2015.

11. RE V., SACCHI E., ALLAIS E. The use of nitrate isotopes to identify contamination sources in the Bou-Areg aquifer (Morocco). Procedia Earth and Planetary Science, 7, 729, 2013.

12. ZHOU X. A method for estimating the fresh water-salt water interface with hydraulic heads in a coastal aquifer and its application. Geoscience Frontiers, 2 (2), 199, 2011.

13. HEIL K., SCHMIDHALTER U. Characterisation of soil texture variability using the apparent soil electrical conductivity at a highly variable site. Computers and Geosciences, 39, 98, 2012.

14. SAEY T., DE SMEDT P., DELEFORTRIE S., VAN DE VIJVER E., VAN MEIRVENNE M. Comparing oneand two-dimensional EMI conductivity inverse modeling procedures for characterizing a two-layered soil. Geoderma, 241, 12, 2015.

15. STADLER A., RUDOLPH S., KUPISCH M., LANGENSIEPEN M., VAN DER KRUK J., EWERT F. Quantifying the effects of soil variability on crop growth using apparent soil electrical conductivity measurements. European journal of agronomy, 64, 8, 2015.

16. BEKELE A., HUDNALL W.H., DAIGLE J.J., PRUDENTE J.A., WOLCOTT M. Scale dependent variability of soil electrical conductivity by indirect measures of soil properties. Journal of Terramechanics 42 (3), 339, 2005.

17. MURATA H., FUTAGAWA M., KUMAZAKI T., SAIGUSA M., ISHIDA M., SAWADA, K. Millimeter scale sensor array system for measuring the electrical conductivity distribution in soil. Computers and Electronics in Agriculture, 102, 43$50,2014$.

18. SUDDUTH K.A., KITCHEN N.R., WIEBOLD W.J., BATCHELOR W.D., BOLLERO G.A., BULLOCK D.G., CLAYE D.E., PALM H.L., PIERCE F.J., SCHULER R.T., THELEN K. D. Relating apparent electrical conductivity to soil properties across the north-central USA. Computers and Electronics in Agriculture, 46 (1), 263, 2005.

19. AMAKOR X.N., JACOBSON A.R., CARDON G.E, HAWKS A. A comparison of salinity measurement methods based on soil saturated pastes. Geoderma 219, 32, 2014.

20. RONG-JIANG Y.A.O., JIN-SONG Y.A.N.G., GUANGMING L.I.U. Calibration of soil electromagnetic conductivity in inverted salinity profiles with an integration method. Pedosphere, 17 (2), 246, 2007.

21. ADAM I., MICHOT D., GUERO Y., SOUBEGA B., MOUSSA I., DUTIN G., WALTER C. Detecting soil salinity changes in irrigated Vertisols by electrical resistivity 
prospection during a desalinisation experiment. Agricultural water management 109, 1, 2012.

22. VITHARANA U. W., VAN MEIRVENNE M., SIMPSON D., COCKX L., DE BAERDEMAEKER J. Key soil and topographic properties to delineate potential management classes for precision agriculture in the European loess area. Geoderma, 143 (1), 206, 2008.

23. TAYLOR J.A., COULOUMA G., LAGACHERIE P., TISSEYRE B. Mapping soil units within a vineyard using statistics associated with high-resolution apparent soil electrical conductivity data and factorial discriminant analysis. Geoderma, 153 (1), 278, 2009.

24. SUDDUTH K.A., MYERS D.B., KITCHEN N.R., DRUMMOND S.T. Modeling soil electrical conductivitydepth relationships with data from proximal and penetrating EC a sensors. Geoderma, 199, 12, 2013.

25. CORWIN D.L., LESCH S.M., OSTER J.D., KAFFKA S.R. Monitoring management-induced spatio-temporal changes in soil quality through soil sampling directed by apparent electrical conductivity. Geoderma, 131 (3), 369, 2006.

26. FARZAMIAN M., SANTOS F.A.M., KHALIL M.A. Application of EM38 and ERT methods in estimation of saturated hydraulic conductivity in unsaturated soil. Journal of Applied Geophysics 112, 175, 2015.

27. AINI I.N., EZRIN M.H., AIMRUN W. Relationship between soil apparent electrical conductivity and $\mathrm{pH}$ value of Jawa Series in oil palm plantation. Agriculture and Agricultural Science Procedia, 2, 199, 2014.

28. KITCHEN N.R., SUDDUTH K.A., MYERS D.B., DRUMMOND S.T., HONG S.Y. Delineating productivity zones on claypan soil fields using apparent soil electrical conductivity. Computers and Electronics in Agriculture, 46 (1), 285, 2005.

29. CORWIN D.L., PLANT R.E. Applications of apparent soil electrical conductivity in precision agriculture. Computers and Electronics in Agriculture 46 (1), 1, 2005.

30. HU W., SHAO M.A., WAN L., SI B.C. Spatial variability of soil electrical conductivity in a small watershed on the Loess Plateau of China. Geoderma 230, 212, 2014.

31. MCCUTCHEON M.C., FARAHANI H.J., STEDNICK J.D., BUCHLEITER G.W., GREEN T.R. Effect of soil water on apparent soil electrical conductivity and texture relationships in a dryland field. Biosystems Engineering, 94 (1), 19, 2006.

32. ARCHIE G.E. The electrical resistivity $\log$ as an aid in determining some reservoir characteristics. Trans. AIMME, 46, 54, 1942.

33. NIWAS S., CELIK M. Equation estimation of porosity and hydraulic conductivity of Ruhrtal aquifer in Germany using near surface geophysics. Journal of Applied Geophysics, 84, 77, 2012

34. EBONG E.D., AKPAN A.E., ONWUEGBUCHE A.A.. Estimation of geohydraulic parameters from fractured shales and sandstone aquifers of Abi (Nigeria) using electrical resistivity and hydrogeologic measurements. Journal of African Earth Sciences, 96, 99, 2014.

35. SOUPIOS P. M., KOULI M., VALLIANATOS F., VAFIDIS A., STAVROULAKIS G. Estimation of aquifer hydraulic parameters from surficial geophysical methods: A case study of Keritis Basin in Chania (Crete-Greece). Journal of Hydrology, 338 (1), 122, 2007.

36. NAKATSUKA Y., XUE Z., YAMADA Y., MATSUOKA T. Experimental study on monitoring and quantifying of injected $\mathrm{CO}_{2}$ from resistivity measurement in saline aquifer storage. Energy Procedia, 1 (1), 2211, 2009.

37. PERDOMO S., AINCHIL J.E., KRUSE E. Hydraulic parameters estimation from well logging resistivity and geoelectrical measurements. Journal of Applied Geophysics, 105, 50, 2014

38. DI MAIO R., PIEGARI E., TODERO G., FABBROCINO S. A combined use of Archie and van Genuchten models for predicting hydraulic conductivity of unsaturated pyroclastic soils. Journal of Applied Geophysics, 112, 249, 2015.

39. ALCÁNTAR-ELIZONDO R. Variability temporal space of the beach profile, in Las Glorias beach. Master Thesis. Instituto Politécnico Nacional, México. 2007 [In Spanish].

40. ZAYAS ESQUER M. M. Effect on Las Glorias beach caused by the construction of espogón when modifying coastal transport. Master>s Thesis. Instituto Politécnico Nacional, México, 2010 [In Spanish].

41. ZAYAS ESQUER M.M., ESPINOZA CARREÓN L.T., JIMÉNEZ ILLESCAS R. Modification of coastal hydrological dynamics caused by the construction of a breakwater at Las Glorias beach, Guasave, Sinaloa, XII Congress of the Sea Cortes Researchers Association and VI International Symposium on Mar de Cortés, Guaymas, Sonora, México, 2010 [In Spanish].

42. ROCHA H., CARDONA A., GRANIEL E., ALFARO C., CASTRO J., RÜDE T., HERRERA E., HEISE L. Interfaces of freshwater and brackish water in the region of MeridaProgreso, Yucatán. Tecnología y ciencias del agua, 6 (6), 89, 2015 [In Spanish].

43. CUSTODIO E., LLAMAS R. Underground hydrology. Vol. 1 y 2. Barcelona: Ed. Omega. 1976 [In Spanish].

44. INEGI (NATIONAL INSTITUTE OF STATISTIC AND GEOGRAPHY). Municipal statistical notebook, Guasave, Sinaloa. Aguascalientes, Mexico, First Edition, 2000 [In Spanish].

45. INEGI (NATIONAL INSTITUTE OF STATISTIC AND GEOGRAPHY). Municipal Geographical Information Handbook of the United Mexican States Guasave, Sinaloa Geostatistical key 25011. México, 2009 [In Spanish].

46. CONAGUA (National Water Comission). Technical file justifying the aquifer of the Sinaloa River for the publication of the availability in the Official Gazette of the Federation. Culiacán, Sinaloa, México, 2002 [In Spanish].

47. KELLER G.V., FRISCHKNECHT F.C. Electrical methods in geophysical prospecting. Pergamon Press Inc., Oxford, 1966.

48. Orellana E. Geoelectric prospecting by variable fields. Technical Library Philips, Paraninfo, España. 1974 [In Spanish].

49. GF INSTRUMENTS, S.R.O. Short guide for electromagnetic conductivity mapping and tomography, Purkyňova, Brno, Czech Republic, 2013.

50. SEMARNAT R.N. NOM-021-RECNAT-2000, Official Gazette of the Federation, December 31, México, 2002 [In Spanish].

51. BOUYOUCOS G.J. Hydrometer method improved for making particle size analyses of soils. Agronomy Journal, $\mathbf{5 4}$ (5), 464, 1962.

52. HEATH R.C. Basic Ground-Water Hydrology. U.S. Geological Survey Water-Supply paper 2220. United States Geological Survey, 1983.

53. CHOO H., BURNS S. E. Review of Archiess equation through theoretical derivation and experimental study on uncoated and hematite coated soils. Journal of Applied Geophysics, 105, 225, 2014.

54. HIMI M., SANZ N., TAPIAS J.C., CASAS A. Usefulness of geophysical methods in the delimitation of marine intrusion in coastal aquifers. Coastal aquifers and desalination plants, 79, 2002 [In Spanish]. 
55. POTOSÍ G., DAVID L. Evaluation of three soil pH correctors in the agronomic behavior of the capsicum (Capsicum annuum L.), Tropical Irazú variety in the Urcuquí canton, in the province of Imbabura (Bachelor's thesis, Babahoyo: UTB, 2011). 2011 [In Spanish].

56. ARMANDO J. Effect of different concentrations of seawater on the growth and germination of tomato genotypes (Lycopersicon esculentum Mill.) (Bachelor>s thesis, La Libertad: Universidad Estatal Península de Santa Elena). 2015 [In Spanish].
57. BOHN V., PICCOLO M., PERILlO G. Potencial uso agrícola del agua de la laguna Unamuno. Buenos Aires, Argentina. Revista Ecosistemas, 16 (2), 77, 2007 [In Spanish].

58. RAMOS-REYES R., GAMA CAMPILLO L.M, NUÑEZ GÓMEZ J.C., SÁNCHEZ HERNÁNDEZ R., HERNANDEZ TREJO H., RUIIZ ÁLVAREZ O. Adaptation of the model of coastal vulnerability in the Tabasqueño coast to climate change. Revista Mexicana de Ciencias Agrícolas, Special publication 13, 2551, 2016 [In Spanish]. 